\title{
Biocompatibility Evaluation of a New Bioresorbable Pin for Membrane Fixation
}

\author{
Tania Mary CESTARI ${ }^{1}$ \\ Rodrigo Cardoso de OLIVEIRA ${ }^{1}$ \\ Jefferson Tomio SANADA ${ }^{1}$ \\ Gustavo Pompermaier GARLET ${ }^{1}$ \\ Rumio TAGA ${ }^{1}$ \\ José Mauro GRANJEIRO2,3

\begin{abstract}
${ }^{1}$ Department of Biological Sciences, Bauru Dental School, University of São Paulo, Bauru, SP, Brazil
${ }^{2}$ Department of Cell and Molecular Biology, Institute of Biology, Fluminense Federal University, Niterói, RJ, Brazil

${ }^{3}$ Bioengineering, Directory of Programs, INMETRO, Duque de Caxias, RJ, Brazil
\end{abstract}

\begin{abstract}
The aim of this study was to morphometrically analyze the tissue response to a customized pin obtained from devitalized bovine cortical bone (DBCB-pin) implanted in the subcutaneous tissue of rats, as well as to assess its microstructural aspect by scanning electron microscopy (SEM). The pins were implanted in the subcutaneous tissue of 20 rats, which were killed at 7, 14, 28 and 60 days (5 rats/ period) after implantation. In the subcutaneous tissue, DBCB-pin promoted the formation of a fibrous capsule. At 7 days, capsule showed thickness of $70 \pm 3.2 \mu \mathrm{m}$ with higher density of newly formed capillaries and smaller density of collagen fibers. Between 14 and 60 days, more organized fibrous capsule exhibited smaller thickness $(53 \pm 5.5 \mu \mathrm{m})$ with higher density of fibroblasts and collagen fibers. In this period, a small and slow bioresorption of the DBCB-pin by macrophages and rare multinucleated giant cells without tissue damage was observed. The thickness of DBCB-pin resorbed was in mean only of $9.3 \mu \mathrm{m}$. During all experimental periods not occurred presence of immune reaction cells as lymphocytes and plasma cells. It was concluded that the pin derived from cortical bovine bone was well tolerated by subcutaneous tissue of rats and slowly resorbed could be an alternative material for membrane fixation in the guided tissue regeneration procedures.
\end{abstract}

Key Words: biocompatibility, resorbable pin, guided tissue regeneration, connective tissue reaction.

\section{INTRODUCTION}

Materials for treatment of facial bone fractures were developed during the 1980's, such as screws and plates to act as membrane stabilizers, or as stabilization points in orthognathic surgery (1). The biocompatibility of these devices has been assessed by observation of the interface between the screw and the bone tissue, since these should be inert to the body and resistant to physiological movements (2).

Metallic plates and screws have been used in the routine way of stabilizing the craniofacial skeleton. However, there are disadvantages, which include unacceptable palpability, distortion of future magnetic resonance imaging (MRI) scans or computed tomograms
(CT), and passive migration of the metal plates in children (3). The potential need for a second procedure to remove symptomatic metallic fixation has been well documented, particularly because of the relatively young age of many patients in whom they are implanted (3). For that reason, biodegradable polymer screws were developed, such as those of polyglycolic acid (PGA), polylactic acid (PLA) and other homopolymers and copolymers have been studied to replace titanium devices in craniomaxillofacial surgery fixation (4).

Besides the biocompatibility and bioresorption, the resorbable screws must have proper mechanical resistance because they will act on an area subjected to physiological movements (5). Actis et al. (6) observed that the mechanical properties are reduced by longer

Correspondence: Dr. José Mauro Granjeiro, Bioengenharia, Diretoria de Programas, Instituto Nacional Metrologia, Normalização e Qualidade Industrial (INMETRO), Avenida Nossa Senhora das Graças, 50, Prédio 6, Sala da DIPRO, $1^{\circ}$ Andar, Xerém 25250-020, Duque de Caxias, RJ, Brasil Tel.: +55-21-2145-3320. Fax: +55-21-2679-9837. e-mail: jmgranjeiro@inmetro.gov.br 
periods of demineralization and autoclaving for long periods at high pressures. The resorption rate is another important factor as the material should keep its functional integrity and mechanical resistance throughout the most critical phase of bone repair (7).

Recent studies have demonstrated that biomaterials derived from bovine bone are biocompatible (8). This is a material obtained from an abundant and controlled source at low cost. The risk of transmission of diseases such as zoonoses and bovine spongiform encephalopathy ("mad cow disease") is low, due to the extreme mechanical, chemical and thermal processes to which the bovine bone is subjected (9). The entire mineral (demineralization) and/or organic (thermal deproteinization) component of bovine bone can be eliminated, depending on the type of processing $(8,9)$. The materials obtained by these processes are generally called demineralized and anorganic bone, respectively, referring to the predominant component. However, despite the high osteoconductive potential of the cortical anorganic bone its mechanical resistance is low (10).

Conversely, extreme chemical processing with caotropic agents, alkalis and organic solvents allows devitalization of the bovine bone with maintenance of the collagen and hydroxyapatite structure. This result in a mixed bovine bone implant (MBB), its handling to the pins shape that may be employed for fixation of membranes in guided tissue regeneration (GTR) and guided bone regeneration (GBR), due to its high mechanical resistance.

The use of xenogenic tissues as a source of biomaterials is not new. The processing procedures must assure the complete removal of immunogenic compounds to eliminate the risk of disease transmission and reduce the potential of the material to trigger immunological antibody reaction from the host tissue (9). The great challenge is the production of a material with adequate mechanical and physicochemical properties, biocompatibility, predictability, and clinical application, reduced trans-operative and postoperative risks (4).

Due to the complex nature of the human body, specific problems with biomaterial biocompatibility and function are almost impossible to predict without extensive testing in cell cultures as well as in living systems. In general, tissue biocompatibility of a material has been described in terms of the acute and chronic inflammatory response and the fibrous capsule formation after several time periods following implantation.

In this study, initial preclinical evaluation of biocompatibility of devitalized cortical bovine bone pin was made in a standardized study testing rat subcutaneous model, as suggested by the Biological Evaluation of Medical Device Technical Committee of the International Organization for Standardization (ISO) document 10993-6.

The aims of the present study were to characterize the surface of mixed bovine cortical bone pins by scanning electron microscopy (SEM) and to conduct a morphometric analysis of the tissue response around pins implanted in subcutaneous tissue of rats. The positive hypothesis is that pins of devitalized cortical bovine bones are well tolerated by subcutaneous tissue. The null hypothesis is that the material is not well tolerated.

This study represents a first step in the investigation of mixed bovine cortical bone pins biocompatibility aiming at establishing their potential as a fixation device in the GTR and GBR.

\section{MATERIAL AND METHODS}

\section{Test Material}

Bovine bones were obtained at the local slaughterhouse, mechanically processed and chemically treated with alkalis, organic solvents and caotropic agents for devitalization (Baumer SA, Mogi Mirim, SP, Brazil). The end product - devitalized bovine cortical bone (DBCB-pin) - is a cell-free bovine matrix composed by native collagen I and mineral, maintaining the mechanical proprieties of bone. Blocks of cortical devitalized bone was used to produce the pins $(5 \times 1 \mathrm{~mm}$, length $\mathrm{x}$ point diameter) using the lath with irrigation and sterilized (gamma radiation).

\section{SEM Analysis}

For the microstructural analysis, DBCB-pin samples $(\mathrm{n}=5)$ were mounted on aluminum stubs,

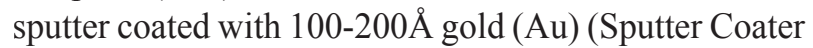
model MED 010 from Balzers, Brügg, Switzerland) and examined with a scanning electron microscope (Carl Zeiss, Oberkochen, Germany) at magnifications between $20 \times$ and $1000 \times$ and $10-15 \mathrm{kV}$ acceleration potentials. The images were captured using DITI software (Carl Zeiss).

\section{Animals}

Twenty adult (90 days-old), male white Wistar 
rats (Rattus norvegicus) weighing approximately 160 $\mathrm{g}$ were randomly divided into 4 experimental groups, according to the periods of $7,14,28$ and 60 days postsurgery ( 5 animals/period).

The guidelines for care and use of laboratory animals (COBEA, Brazilian College of Animal Experimentation) were strictly followed and approved by the Ethics Committee for Teaching and Research in Animals of Bauru Dental School, University of São Paulo, Brazil.

\section{Surgical Procedures for Pin Implantation}

The same sequence of procedures was followed for all rats. Animals were weighed and anesthetized with an intramuscular injection of ketamine hydrochloride ( $35 \mathrm{mg} / \mathrm{kg}$ body weight) and xylazine hydrochloride (6 $\mathrm{mg} / \mathrm{kg}$ body weight), purchased from Agribrands do Brasil Ltda. (Paulínea, SP, Brazil). After anesthesia, the dorsum of the animals was shaved and cleaned with iodated alcohol. A 1-cm incision was cut on the skin of the the animal's back, with dissection of the underlying subcutaneous tissue with blunt-tipped scissors, yielding a cavity measuring approximately $2 \mathrm{~cm}$. One DBCB-pin/ animal was gently accommodated in the cavity, and the incision edges were sutured with 4-0 black silk suture (Ethicon - Johnson \& Johnson, Somerville, NJ, USA), followed by asepsis with iodated alcohol. During the entire experimental period, the rats received normal diet (food and water) ad libitum, and were kept in individual cages with wood bedding.

\section{Histological Procedures}

At completion of the experimental periods, the rats were sacrificed with an overdose of anesthetics. The remaining pin and reaction tissue was located by inspection and palpation, removed together with the skin and fixed in $10 \%$ formalin in phosphate buffer for 7 days. The specimens were demineralized in Morse solution $(50 \%$ formic acid and $20 \%$ sodium citrate, $1: 1)$ at environment temperature for approximately 30 days, with weekly changes of the solution. After demineralization, the specimens were dehydrated in ethyl alcohol in increasing concentrations, cleared in xylol, and embedded in paraffin with synthetic resin Histosec (Merck KGaA, Darmstadt, Germany). Semiserial 6 - $\mu \mathrm{m}$-thick longitudinal sections were obtained and stained with hematoxylin and eosin (HE).

\section{Histological Analysis}

All histological sections were analyzed with an Axioscop $^{\text {TM }}$ light microscope (Carl Zeiss) based on the following references: integrity of DBCB-pin, resorption areas, fibrous tissue involvement and occurrence and types of inflammatory infiltrate.

\section{Morphometric Analysis}

Determination of capsule thickness and linear percentage of resorbed DBCB-pin surface: The capsule mean thickness of the fibrous capsule and linear percentage of resorbed DBCB-pin surface were determined for all experimental periods in a system for analysis of digitized images, comprising of a Zeiss Axioscop 2 microscope at $40 \times$ magnification, camera CCD-IRIS RGB camera (Sony Corporation, Tokyo, Japan) and software Kontron KS300 (Kontron Elektronik $\mathrm{GmbH}$, Image Analysis Division, Echinf, Munich, Germany) coupled to an IBM computer. For those purposes, 4 semi-serial longitudinal sections per animal, containing DBCB-pin head and body were used. For determination of capsule thickness 11 images (Fig. 1A) were captured of each section and 6 measurements $(\mathrm{H})$ at $50-\mu \mathrm{m}$ distance (Fig. 1B) were obtained after calibration of units, always perpendicular to the internal surface of the capsule in contact with the material. Average thickness of capsule (Tc) was calculated according to the formula: $\mathrm{Tc}=\left(\mathrm{H}_{1}+\mathrm{H}_{2} \ldots+\mathrm{H}_{66}\right) / 66$. Percentage of resorbed DBCB-pin surface (Fig. 1C) was obtained from the linear measurement of intact $(\mathrm{Si})$ and resorbed $(\mathrm{Sr})$ pin surface. The linear percentage of resorbed DBCB-pin surface (LPSr) was calculated according to the relation $\mathrm{LPSr}=100 \times(\mathrm{Sr} / \mathrm{St})$, where $\mathrm{St}=\mathrm{Si}+\mathrm{Sr}$.

Volume density of each structure in the fibrous capsule: The volume density (Vvi) or the fraction of fibrous capsule volume occupied by the fibroblasts, collagen fibers, vessels, inflammatory infiltrate and other structures (spaces occupied by interstitial liquid) was determined by the point volumetric method, using an CH2-Olympus microscope (Olympus America Inc., New York, NY, USA) with a $100 \times$ objective and $8 \times$ Zeiss $\mathrm{Kpl}$ eyepiece containing a Zeiss II integration grid with 100 points symmetrically distributed over a quadrangular area. Thirty-six histological fields per animal were selected by systematic sampling (11) and the number of points coinciding with each structure (Pi) and the total points analyzed $(\mathrm{P})$ were determined. 
The volume density of each type of structure (Vvi), was calculated according to the equation $\mathrm{Vvi}=\mathrm{Pi} / \mathrm{P}(11)$.

\section{Statistical Analysis}

The morphometric data showed a normal distribution. The groups were compared by ANOVA and post-hoc multiple comparisons were done by the StudentNewman-Keus method using Sigma Stat software (Jadel Corporation, Chicago, IL, USA) at 5\% significance level.

\section{RESULTS}

\section{SEM Analysis}

The SEM analysis revealed that the DBCB-pin (Fig. 2) had a compact structure, similar to the cortical bone with an anchoring head (Fig. 2A) for a structural element, the pin body. The DBCB-pin body (Fig.2A) was composed by two segments in sequence, from head (crestal) to apical. The first segment adjoined the anchoring head and showed a constant outer diameter. The second segment was shorter, tapering apically. The head (Fig. 2B) and body (Fig. 2C) surfaces showed slots, grooves and waving, due to the fabrication process.

\section{Morphologic Analysis}

The morphological evaluation of the histological sections throughout the experimental periods revealed the formation of a clear fibrous capsule around the DBCB-pin (Fig. 3). No areas of necrosis, foreign body inflammatory reaction or signs of activation of the adaptative immune system were found at any specimen during the observational periods.

At 7 days, a thick fibrous capsule was observed around the DBCB-pin. A disorganized collagen fiber network with several newly formed vessels, fibroblasts and interstitial spaces and some polymorphonuclear neutrophils (PMNs) and macrophages composed the capsule. These morphological characteristics of the capsule revealed normal wound healing due to surgical trauma. The DBCB-pin structure was intact (nonresorbed) with large pores filled with blood clot and empty small pores.

At 14 days, the thickness of the fibrous capsule decreased and presented rare inflammatory cells. Organized collagen fibers and several elongated fibroblasts with an arrangement rather parallel to DBCBpin surface constituted the capsule. In the capsule, the number and diameter of blood vessels decreased significantly in opposition to which was observed in the adjacent loose connective tissue. DBCB-pin structure did not change comparing to the 7-day period.

At 28 days, the fibrous capsule was wellorganized with denser collagen fibers, few interstitial spaces and several elongated fibroblasts. The adjacent area of DBCB-pin surface presented some macrophages
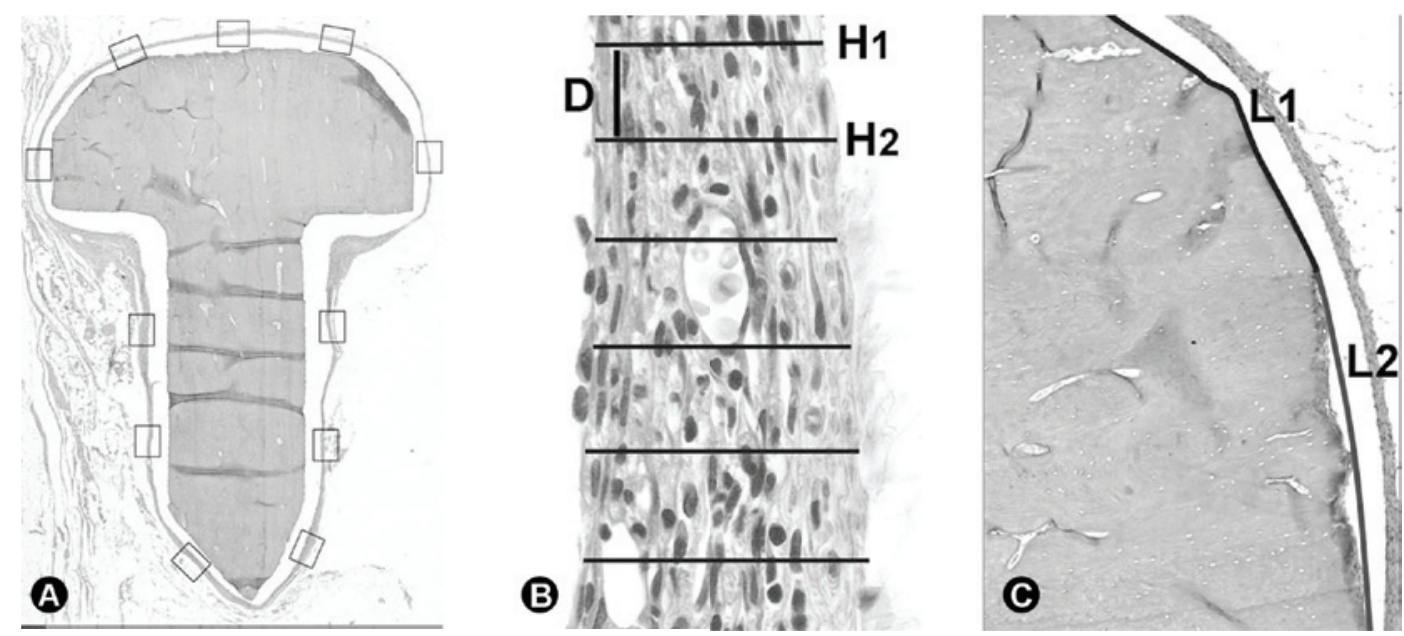

Figure 1. Morphometric measurements: $\mathrm{A}=11$ areas evaluated per image for determination of capsule thickness; $\mathrm{B}=$ measurements $\left(\mathrm{H}_{1}\right.$ and $\left.\mathrm{H}_{2}\right)$ obtained of capsule thickness at $50 \mu \mathrm{m}$ of distance $(\mathrm{D})$ with an $40 \times$ objective; and $\mathrm{C}=$ linear measures of intact $\left(\mathrm{L}_{1}\right)$ and resorbed $\left(\mathrm{L}_{2}\right)$ DCBB-pin surface with an $10 \times$ objective. 

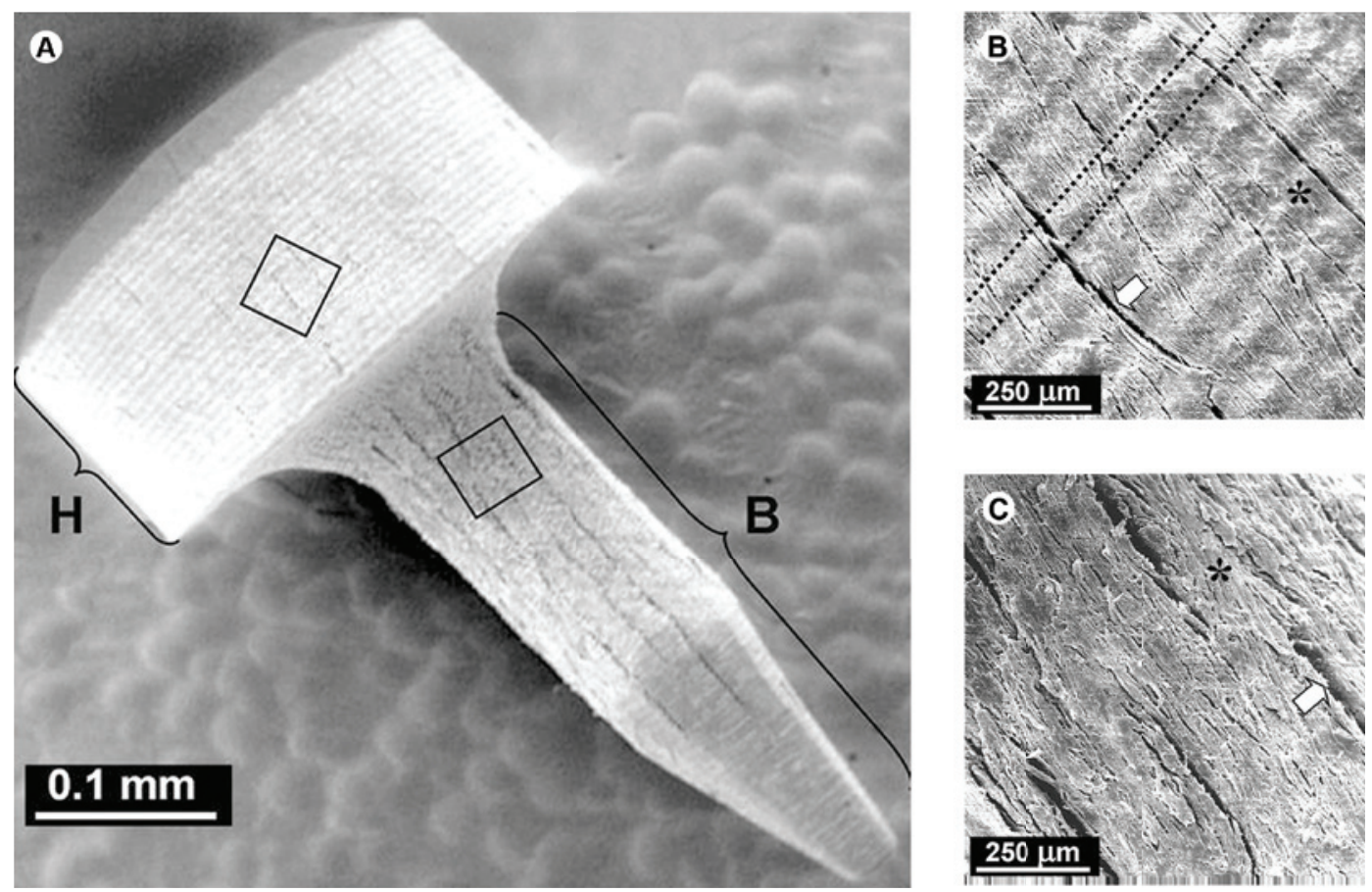

Figure 2. SEM micrograph of DCBB-pin. A= Panoramic aspects showing compact structure of head (H) and body (B) pin, similar to the cortical bone; $\mathrm{B}=$ Detail of the pin head $(\mathrm{H})$ exhibiting waving (point lines) and grooving (white arrow) in the manufactured surface (asterisk); $\mathrm{C}=$ detail of pin body showing grooving (white arrow) in the manufactured surface (asterisk).

and rare multinucleated giant cells. No other type of inflammatory cells was observed. The outside surface and inside surface of large pores occupied by cells of the adjacent connective tissue in the DBCB-pin exhibited resorption areas.

At 60 days, the fibrous capsule was better

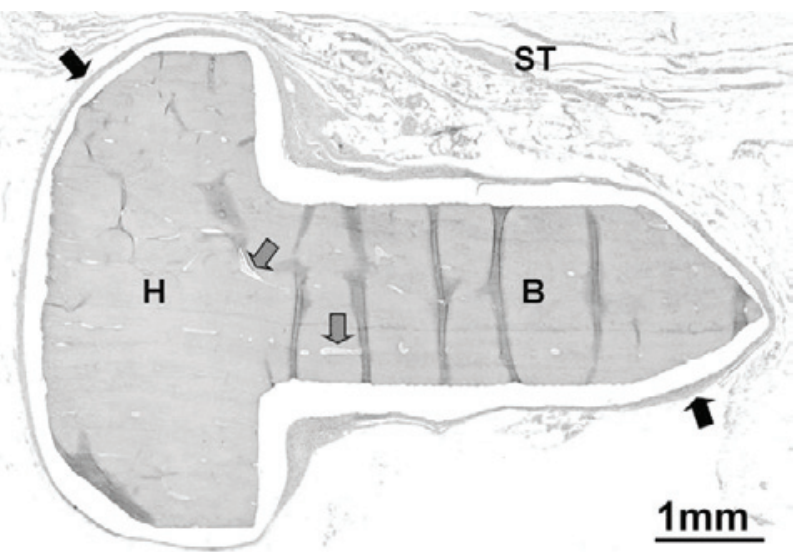

Figure 3. Photomicrograph of DCBB-pin 14 days after implantation in subcutaneous tissue (ST) involved by a fibrous capsule (black arrows), showing the head (H) and body (B) composed by compact structure with some small pores (gray arrows). HE. organized than in the previous period, but with similar thickness and number of fibroblasts. In the DBCB-pin surface, the resorption rate was higher in relation to the previous period.

\section{Morphometric Analysis}

Summarized morphometric data of the fibrous capsule (thickness and volume density of fibers, fibroblasts, vessels, inflammatory cells and other structures) and DBCB-pin surface (linear resorption) are presented in Table 1.

\section{Thickness and Density Volume of the Fibrous Capsule}

At 7 days, the mean capsule thickness was 70.87 $\mu \mathrm{m}$ with 50.5 and $22.6 \%$ occupied by collagen fibers and fibroblasts, respectively. In this period there was major percentage of vessels (13.2\%), inflammatory cells (3.2\%) and other structures $(10.37 \%)$ in relation to the other periods. At 14 days, capsule thickness decreased by $25 \%$, but the percentage of collagen fibers increased $23 \%$, while that the vessels, inflammatory cells and other structures decreased by 42,32 and $36 \%$, respectively. 
At 28 days, capsule thickness did not show statistically significant differences compared to the previous period. The percentage of fibroblast increased by $21 \%$, while the vessels, inflammatory cells and other structures decreased markedly, occupying only 5, 0.6 and $4 \%$ of the tissue volume, respectively. Comparison between 28 and 60 days periods showed no significant differences (Fig. 4).

\section{Percentage of Linear Resorption of Pin Surface}

At 7 days, DBCB-pin surface did not show signal of resorption. After 14 days, small areas of resorption were observed only on the pin surface with a linear percentage of $1.0 \%$, increasing substantially until 60 days $(40.0 \%)$. The thickness of DBCB-pin resorbed surface (perpendicular to pin surface) was only of 9.3 $\pm 4.86 \mu \mathrm{m}$ on the average (Fig. 5).

\section{DISCUSSION}

GBR is a therapy used in dentistry for the reconstruction of osseous defects around teeth, dental implants, and prior to implant placement. In this therapy, a membrane barrier is used to cover bone defects and to prevent mechanically the invasion of undesirable cells of the surrounding soft tissues, creating a secluded space favorable at bone regeneration. In addition, bioabsorbable membranes have been made for regeneration procedures, eliminating the need of a second surgical procedure for removal of the barrier, as in the case of the non-resorbable membrane. However, bone formation enhances significantly when the membrane is tightly attached and immobilized to the bone surface through the use of membrane fixing pins (12).

DBCB-pin implanted in the subcutaneous tissue of rats induced a mild inflammatory reaction, which may be related to the initial trauma, secondary to the surgical procedure, decreasing significantly after 14 days. A fibrous capsule was observed in all experimental period, encircling DBCB-pin surface. In the initial periods, capsule was thick and showed higher density of newly formed capillaries and small collagen fibers, followed by their conversion into a thinner and more organized capsule with higher density of fibroblasts and collagen fibers. In this period, DBCB-pin showed mild and slow bioresorption by macrophages and rare multinucleated giant cells, without tissue damage.

On the other hand, previous studies, evaluating anorganic and organic bovine or human bones implanted in the rat subcutaneous tissues showed the mobilization of several multinucleated giant cells around the implants $(8,13)$. The slow and superficial resorption of DBCB-pin with small numbers of macrophages and multinucleated giant cells observed here could be due to the form and topography of the DBCBpin surface. The high surface-to-volume ratio to the particulate materials analyzed in the abovecited studies favored the presence of larger numbers of macrophages and foreign body giant cells on the implant surface, and consequently a higher tissue damage,

Different letters indicate statistically significant difference at $\mathrm{p}<0.05$. 
while the lower surface area and compact form of the DBCB-pins promoted fibrosis as a significant component of the implant site $(8,13)$. The foreign body reaction, consisting mainly of macrophages may persist at the tissue-implant interface for the lifetime of the implant.

The good biocompatibility of DBCB-pin can be reinforced by the absence of immune reacting cells as lymphocytes and plasma cells. Regarding the presence of macrophages and rare multinucleated giant cells in the DBCB-pin surface, recently evidence has shown the importance of macrophage subsets in the foreign body reaction and consequently in the biocompatibility of biomaterials. In areas of fibrosis, active macrophages generate soluble mediators that associated with growth factors (as TGF- $\beta$ and PDGF), which modulate fibroblast proliferation and extracellular matrix production, contributing therefore to the fibrotic process (14).

Besides biocompatibility, DBCB-pins should have enough mechanical properties to withstand biomechanical stress forces that may act on the implanted site during function. Some reports indicate that one of the causes of pin- or screw-secured implant failures are due to premature breakdown of the pins or screws that lost the implant material compromising the healing (15). The mechanical properties of such xenograft retaining devices are dependent on the manufacturing procedures (6). In this respect, the mechanical properties of the pins tested in this study are not yet available; however, it is known that they were fabricated without demineralization and sterilized by gamma radiation.

It should be pointed out that the xenogenic bone biomaterial produced by Tutoplast ${ }^{\mathrm{TM}}$ for the European market show similar composition to that of the DBCBpin. The end product is a cell-free bone matrix with native collagen I and mineral, preserving elasticity and compressive strength of the original bone (16).

There are only few reports on pins produced with processed cortical bone of the bovine or human (17). Conversely, derivatives of bioresorbable synthetic polymers have been widely investigated, especially regarding their biocompatibility and resorption period. Among the most commonly used bioresorbable polymers
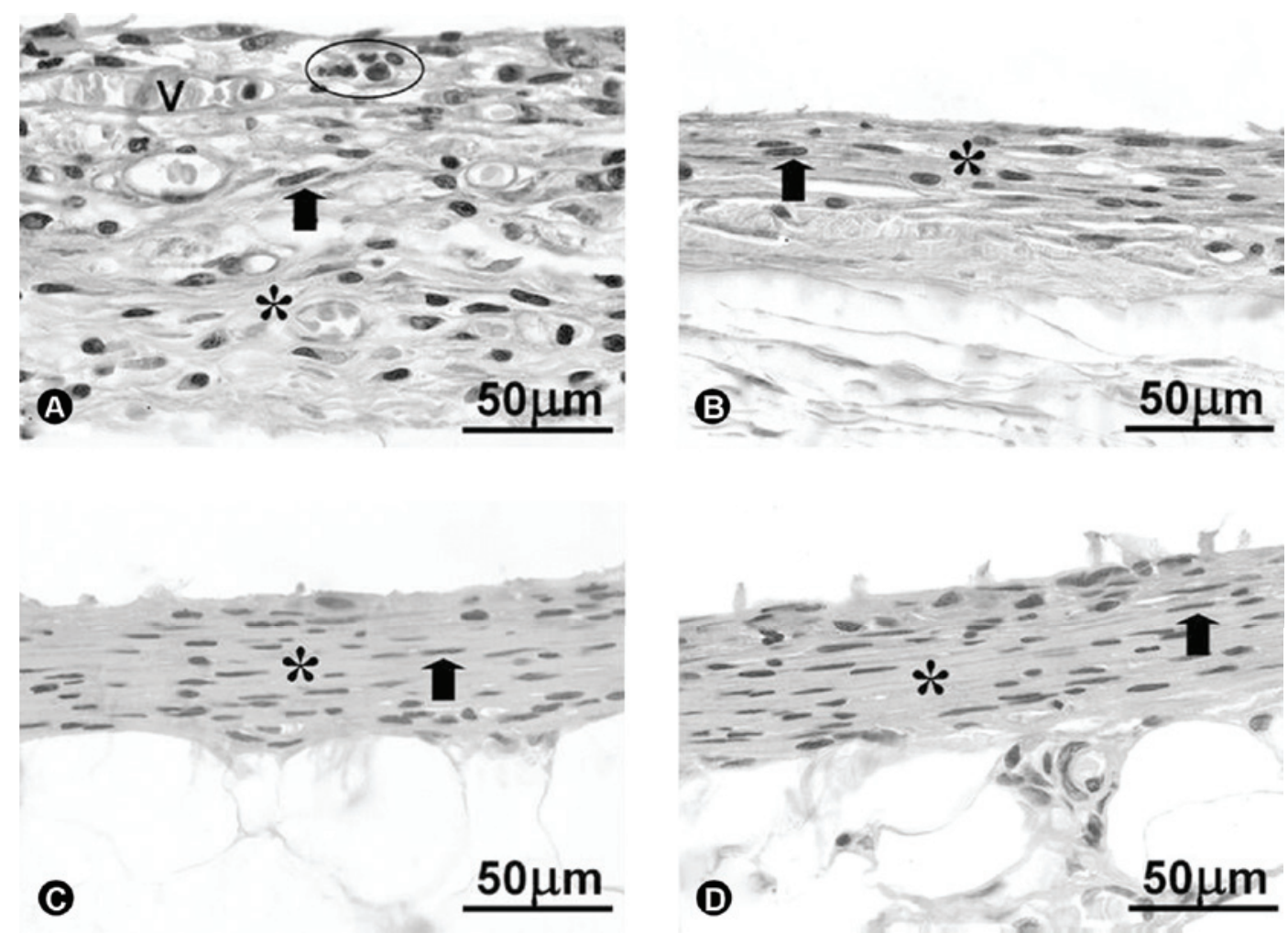

Figure 4. Photomicrograph of fibrous capsule around of DCBB-pin: A= period of 7 days showing thick capsule with several vessels (V), some mononucleated inflammatory cells (circle), collagen fibers (asterisk) disorganized and fibroblasts (black arrow); $\mathrm{B}=$ period of 14 days exhibiting fine capsule with collagen fibers (asterisk) and fibroblasts (black arrow) in organization; $\mathrm{C}-\mathrm{D}=$ periods of, respectively, 28 and 60 days, showing similar morphology with dense collagen fibers and elongated fibroblasts parallels at pin surface. HE. 
for manufacturing of such implants are polyglycolic acid (PLGA), polylactic acid (PLA) and their copolymers. These materials are already employed in dental clinics as drug releasing systems.

Synthetic bioabsorbable polymers of PLGA and PLA and their copolymers are generally well tolerated by living tissues and its bioabsorption generally occurs in two phases. The resulting products of the PLA and PGA degradation are metabolized in carbon dioxide and water and they are eliminated through respiration or urine (18). The timing of the foreign- body response is thought to be related to the stage of polymer degradation, but non-specific inflammatory reaction (18). Animal studies have shown that the in vivo degradation of PGA implants is usually complete after 1 year post-implantation (18) and was depending of physical-chemical characteristics and animal model. It is worthwhile to emphasize that biocompatibility assay in subcutaneous tissue represents a the second level of biocompatibility, following cytotoxicity assay, and intend to provides better knowledge concerning the inflammatory and immune responses induced by
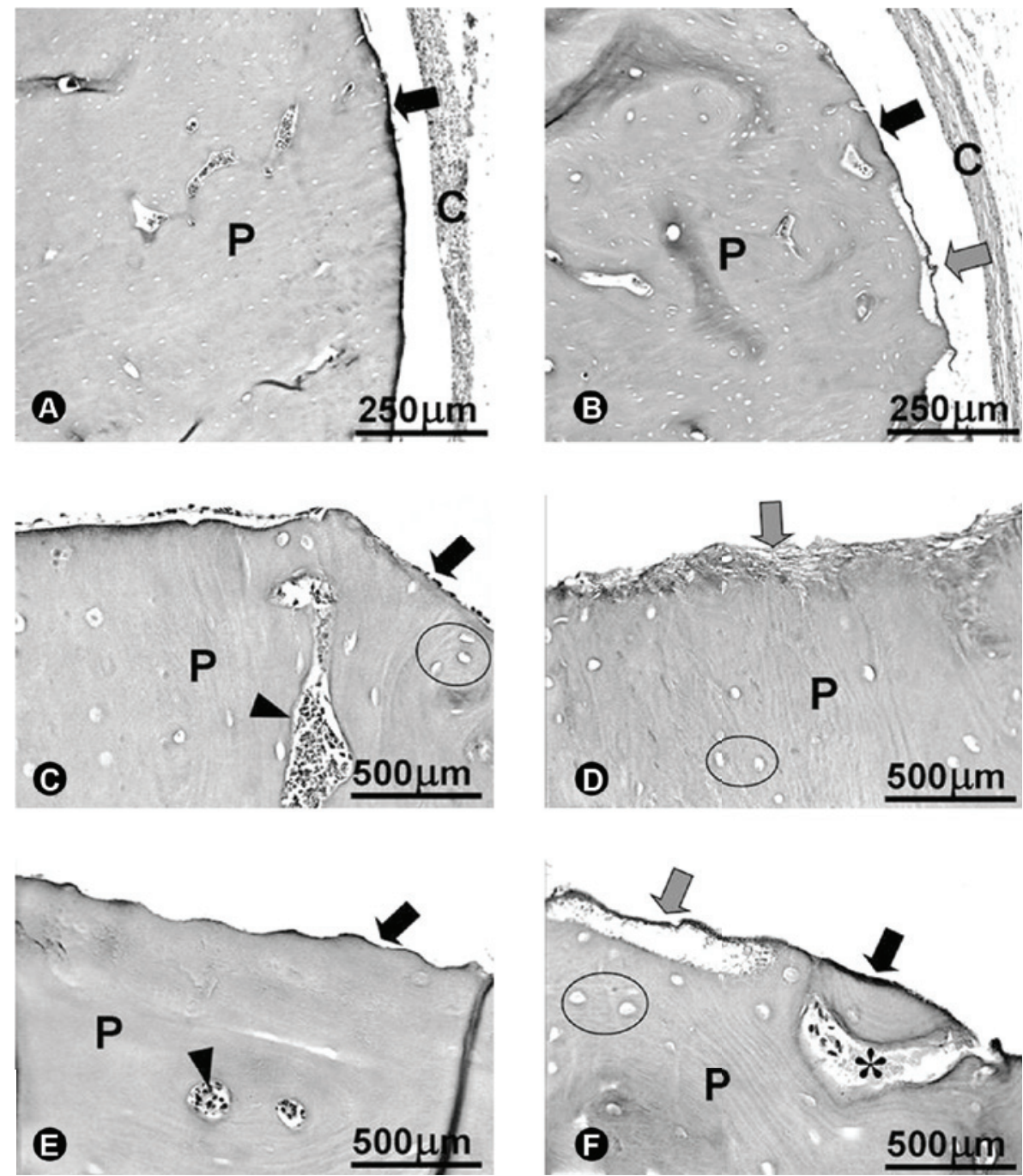

Figure 5. Photomicrograph of DCBB-pin surface: $A=$ at 7 days, panoramic aspect of pin $(\mathrm{P})$ showing non-resorbed surface (black arrow) and fibrous capsule (C); $\mathrm{B}=$ pin head (P) exhibiting non-resorbed surface, large pores (arrowhead) filled by blood clot and small empty pores (circular area); $\mathrm{C}=$ pin body $(\mathrm{P})$ showing waving in the no-resorbed surface and pores filled by blood clot (arrowhead); $\mathrm{D}=$ at 21 days, panoramic aspect of pin (P) showing non-reabsorbed (black arrow) and reabsorbed (gray arrow) surfaces and adjacent fibrous capsule (C); E-F= pin (P) surface showing non-resorbed (black arrow) and resorbed (gray arrow) areas; large pores filled by cells (asterisk) and small empty pores (circular area). HE. 
the test material (19). Also, biomechanics test should be conducted (20).

Based on the present outcomes, it may be concluded that the pin derived from cortical bovine bone was well tolerated by the subcutaneous tissue of rats and lately resorbed. Thus, the anticipated null hypothesis must be rejected. Further studies are required for revealing the intraosseous and clinical behavior of this biomaterial.

\section{RESUMO}

O objetivo deste estudo foi analisar morfometricamente a resposta tecidual a um pino obtido a partir de osso bovino desvitalizado cortical (DBCB pinos) implantado no tecido subcutâneo de ratos, bem como para avaliar o seu aspecto microestrutural por microscopia eletrônica de varredura (MEV). Os pinos foram implantados no tecido subcutâneo de 20 ratos, que foram sacrificados aos 7, 14, 28 e 60 dias (5 animais / período) após a implantação. No tecido subcutâneo, o pino DBCB promoveu a formação de uma cápsula fibrosa. Aos 7 dias, a cápsula apresentou espessura de $70 \pm 3,2 \mu \mathrm{m}$ com maior densidade de capilares neoformados e menor densidade de fibras colágenas. Entre 14 e 60 dias, a cápsula fibrosa apresentava-se mais organizada e exibiram menor espessura $(53 \pm 5,5 \mu \mathrm{m})$ com maior densidade de fibroblastos e fibras colágenas. Nesse período, foi observada uma bioreabsorção pequena e lenta dos pinos $\mathrm{DBCB}$ por macrófagos e raras células gigantes multinucleadas, sem dano tecidual. A espessura dos pinos DBCB reabsorvidos foi em média de apenas $9,3 \mu \mathrm{m}$. Durante todos os períodos experimentais não ocorreu presença de células como linfócitos e células plasmáticas. Concluiu-se que o pino derivado de osso bovino cortical foi bem tolerado pelo tecido subcutâneo de ratos e reabsorvido lentamente, sendo um potencial material alternativo para fixação da membrana nos procedimentos de regeneração tecidual guiada.

\section{ACKNOWLEDGEMENTS}

To FAPESP for the Scientific Initiation Scholarship (grant $\mathrm{n}$. 02/13868-4), to CNPq for the support to the development of the present study, to the staff of the Department of Biological Sciences - Biochemistry and Histology, Ovídio do Santos Sobrinho and Thelma Lopes Silva and Daniela Ceolin; to the Center of Support to Electron Microscopy Investigations Applied to Agricultural Research (NAP/MEPA) - ESALQ-USP, directed by Prof. Elliot Watanabe Kitajima, which allowed the present analyses; and to Baumer S.A. for the material kindly supplied.

\section{REFERENCES}

1. Peltoniemi HH, Tulamo RM, Toivonen T, Hallikainen D, Tormala $\mathrm{P}$, Waris T. Biodegradable semirigid plate and miniscrew fixation compared with rigid titanium fixation in experimental calvarial osteotomy. J Neurosurg 1999;90:910-917.

2. Hirai H, Okumura A, Goto M, Katsuki T. Histologic study of the bone adjacent to titanium bone screws used for mandibular fracture treatment. J Oral Maxillofac Surg 2001;59:531-537.
3. Moe KS, Weisman RA. Resorbable fixation in facial plastic and head and neck reconstructive surgery: an initial report on polylactic acid implants. Laryngoscope 2001;111:1697-1701.

4. Eppley BL, Sadove AM. Resorbable coupling fixation in craniosynostosis surgery: experimental and clinical applications. J Craniofac Surg 1995;6:477-482.

5. Agrawal CM, Athanasiou KA. Technique to control $\mathrm{pH}$ in vicinity of biodegrading PLA-PGA implants. J Biomed Mater Res 1997;38:105-114.

6. Actis $\mathrm{AB}$, Obwegeser JA, Ruperez C. Influence of different sterilization procedures and partial demineralization of screws made of bone on their mechanical properties. J Biomater Appl 2004; 18:193-207.

7. Quereshy FA, Goldstein JA, Goldberg JS, Beg Z. The efficacy of bioresorbable fixation in the repair of mandibular fractures: an animal study. J Oral Maxillofac Surg 2000;58:1263-1269.

8. Zambuzzi WF, Oliveira RC, Pereira FL, Cestari TM, Taga R, Granjeiro JM. Rat subcutaneous tissue response to macrogranular porous anorganic bovine bone graft. Braz Dent J 2006;17:274-278.

9. Wenz B, Oesch B, Horst M. Analysis of the risk of transmitting bovine spongiform encephalopathy through bone grafts derived from bovine bone. Biomaterials 2001;22:1599-1606.

10. Marinak KW, Mellonig JT, Towle HJ. The osteogenic potential of two human demineralized bone preparations using a xenogeneic model. J Periodontol 1989;60:12-18.

11. Weibel ER. Stereological principles for morphometry in electron microscopic cytology. International Review of Cytology 1969;26:235-302.

12. Amano Y, Ota M, Sekiguchi K, Shibukawa Y, Yamada S. Evaluation of a poly-1-lactic acid membrane and membrane fixing pin for guided tissue regeneration on bone defects in dogs. Oral Surg Oral Med Oral Pathol Oral Radiol Endod 2004;97:155-163.

13. Kelly JD, Schneider GB. Morphological and histochemical comparison of the cells elicited by ectopic bone implants and tibial osteoclasts. Am J Anat 1991;192:45-54.

14. Anderson JM, Rodriguez A, Chang DT. Foreign body reaction to biomaterials. Semin Immunol 2008;20:86-100.

15. Lee JH, Ryu HS, Lee DS, Hong KS, Chang BS, Lee CK. Biomechanical and histomorphometric study on the bonescrew interface of bioactive ceramic-coated titanium screws. Biomaterials 2005;26:3249-3257.

16. Meyer S, Floerkemeier T, Windhagen H. Histological osseointegration of Tutobone ${ }^{\circledR}$ : first results in human. Arch Orthop Trauma Surg 2008;128:539-544.

17. Liptak JM, Edwards MR, James SP, Dernell WS, Bachand AM, Withrow SJ. Mechanical characteristics of cortical bone pins designed for fracture fixation. Clin Orthop Relat Res 2007; 456:218-225.

18. Suuronen R, Kallela I, Lindqvist C. Bioabsorbable plates and screws: Current state of the art in facial fracture repair. J Craniomaxillofac Trauma 2000;6:19-27.

19. Martínez Lalis R, Esaín ML, Kokubu GA, Willis J, Chaves C, Grana DR. Rat subcutaneous tissue response to modified Portland Cement, a new mineral trioxide aggregate. Braz Dent J 2009;20:112-117.

20. Jacobsen C, Obwegeser JA. Are allogenic or xenogenic screws and plates a reasonable alternative to alloplastic material for osteosynthesis-A histomorphological analysis in a dynamic system. J Biomech 2010;43:3112-3117.

Accepted June 14, 2010 